\title{
Public-and-private partnership development under conditions of the imperfect legal regulation
}

\author{
Irina Polyakova ${ }^{1}$, Elena Vasilyeva ${ }^{1, *}$ \\ ${ }^{1}$ Moscow State University of Civil Engineering, 129337, 26, Yaroslavskoye Shosse, Moscow, Russia
}

\begin{abstract}
The objective of this research is to consider some controversial issues of the development of public-and-private partnership (and concession agreements as its most common form) in Russia. Some complaints made by arising from Federal Antimonopoly Service of the Russian Federation to some infrastructure projects are reviewed. The authors studied dynamics of private investments into infrastructure projects in the conditions of imperfect legal regulation. The assessment of the validity of the position of Federal Antimonopoly Service is given. It is predicted whether the legislative collisions will prevent the growth of private investments into infrastructure. Recommendations on the development of the mechanism of public-and-private partnership with the observance of antimonopoly regulation, as well as recommendation on the improvement of the legislation in this area are developed. The results of the research can be used by both private participants of public-and-private partnership and the federal, regional and municipal authorities, and also by legislators working on the improvement of the legislative regulation in this area.
\end{abstract}

\section{Introduction}

Public-and-private Partnership (PPP) is the perspective mechanism that allows transferring some functions on creation, development, modernization, maintenance of public property for rendering high-quality services to the population to private economic entities in the conditions of deficiency of budgetary funds.

Certain theoretical basis of PPP has been created in the Russian science already. The greatest contribution to its development was made by modern scientists (economists) and also by representatives of the civil and financial law: A.V. Belitskoy, N.A. Ignatyuk; V.A. Kabashkin; A.A. Rodin; H.M. Salikhov; I.A. Skripnikov; A.A. Spiridonov; S.V. Shorokhov; A.T. Hidzev, etc.

Separate matters of PPP were investigated by K.A. Makarevich (analysis of provisions of the Federal Law "On Public-and-private partnership", implementation of PPP projects on transport and matters of public property). Works of O.N. Petyukova are devoted to the

\footnotetext{
* Corresponding author: elena.chibisova metr@mail.ru angela-1309.m@yandex.ru
} 
research of PPP in the regions of the Russian Federation, to legal regulation of financing of the infrastructure projects [1].

There is already some successful experience of the practical use of PPP in Russia, especially during implementation of projects on the creation and improvement of social and transport infrastructure (for example, during construction of the highway "Western HighSpeed Diameter" in the city of St. Petersburg, reconstruction of the Pulkovo airport).

The concession agreement is recognized to be one of the most demanded and productive forms of public-and-private partnership. But executive authorities do not fully observe the legislation on the concession agreements and on the competition; that results in some negative results: competitions in the concession agreements are nullified, in courts the main conditions of such agreements are challenged [2].

Federal Antimonopoly Service of the Russian Federation (FAS) has great claims on the validity of the use of PPP during implementation of social and transport projects. Questions of FAS to the procedure of passing of the infrastructure projects implemented on the principles of PPP are known to have arisen for the first time, concerning construction of partially paid road Sterlitamak-Magnitogorsk $171 \mathrm{~km}$ long.

Concession on the construction of the paid road in Bashkiria was won by LLC Bashkirdorstroy. The project cost was about 14 billion rubles, at the same time, $25 \%$ of that sum were provided by the investor. Financing was provided by Gazprombank. But after the end of construction, the state had to compensate costs for construction and maintenance of the road. Having considered that, all the expenses of LLC Bashkirdorstroy are compensated by the state, FAS cancelled the competition results on the construction of the road. And the Arbitration tribunal of Moscow supported the antimonopoly department; that excited the market of PPP. FAS considered that if the only source of financing is the budgetary funds, then everything has to be made out as the state order, and it is necessary to select the performer by rules of the contract system. Government contracts, as well as concessions, are possible for 15-20 years, besides, there are contracts of life cycle.

Shares of business and the state are calculated according to the economy of each project. In some cases, it will be more than $50 \%$, in others it will be $25 \%$. The main fears of the market (if changes are accepted) are that it will reduce the circle of investors, which are few now. According to the PPP Center, there are about 40 such projects providing about 270 billion rubles of private investments in Russia, and that will provide one third of private investments into PPP. If FAS considers all the concessions where expenses are compensated to the investor from the budget to be illegal, then such projects as PLATON, the paid highway Moscow-St. Petersburg (M11) and the Central Circle Road and also some more large regional projects will be questionable. By the way, similar mechanisms were used for the road construction in Austria, the USA, Canada and Great Britain.

In these circumstances, even letters of support from the Ministry of Economic Development, the Ministry of Transport of the Russian Federation, Rosavtodor and the state company "Avtodor", which did not agree with the position of FAS on this matter, did not help LLC Bashkirdorstroy in the court. Arbitrators of the Moscow court supported the position of Antimonopoly Service, that at full public financing it cannot be considered to be a concession. Cancellation of the results of one competition is a special case, though with far-reaching consequences. And the antimonopoly department initiates the introduction of amendments to the concession legislation. That should be noticed that FAS intends to stop practice of return of $100 \%$ of investments at the expense of the budget and also to enter the minimum threshold of participation of the private capital in the concession projects. And it can lead to the compression of the market of concessions [3-4].

It is interesting to consider the validity of claims of FAS to the mechanism of PPP during the implementation of social and transport projects. Besides, the authors of the research study the dynamics of private investments into the infrastructure projects, they try 
to understand whether the legislative collisions will prevent the growth of these investments. And at last, it is important to develop some recommendations on the development of the mechanism of PPP with the observance of antimonopoly regulation (on the one hand), and to make recommendations on the improvement of the legislation in this area (on the other hand) [5].

\section{Methods}

The methodological basis of the research was made by the general scientific methods (dialectic, formal and logical, structurally-and-functional), and some special methods, characteristic of economic science (method of comparative analysis, analogies, method of expert evaluations) and jurisprudence (historical-and-legal, legallistic, technical-and-legal, comparative-and-legal). Besides, logical tecniques were used: analogy, generalization and abstraction, analysis, synthesis, deduction and induction, which allowed to provide the sequence of transition in the research from strictly scientific categories to some practical issues. Methods are applied in the complex to the achievement of completeness and objectivity of the research.

First of all, it was necessary to specify the concepts of the state order and concession, their legal interpretation which is still inexact [6].

The difference between the state order and concession is in the fact, that regulation and financing different. Concessions are concluded according to the results of either a competition, or a private concession initiative at which the competition is possible too. According to the decision of the Government of the Russian Federation concessions are allowed, but so far there is only one successful example among the infrastructure projects, that is PLATON, and regions have no such authorities. The state generally conducts the procurement at the only one supplier. By the time of the performance of FAS, suppliers received government contracts for 1 trillion rubles without competition $(23 \%$ of all the state order). Generally, it is purchases according to the decision of the President and the Government of the Russian Federation (the only one supplier has 39\% of all the purchases).

In the existing legislation, participants and regulators of the market of projects of PPP have no understanding of the legal and economic nature of the payment of the concessor. The concepts "reconstruction" and "maintenance" are not stated in the legislation accurately. The requirements to the participants of competitions, correlation of the legislation on the concessions and state procurements also raise questions at the interested parties [7].

It is clear, that the problems, began with the fact that in Russia generally erudite economists, but not the representatives of legal science were engaged in the development of issues of the formation and development of PPP [8].

\section{Results}

The authors analyzed the dynamics of infrastructure projects with the use of PPP under conditions of the existing legal regulation and their possible prospects taking into account the FAS activity.

According to the National PPP Center, despite the reduction and the obvious lack of budget financing of the public infrastructure in Russia, the quantity of infrastructure projects, which realization is enabled with the use of the mechanisms of PPP increases. Since 2014, 550 PPP projects are started in a year on average, providing annual inflow of private investments of 250 billion rubles. Though the quantity of projects decreased in 
2017, nevertheless the same volumes of the contracted investment obligations at the level of 270-288 billion rubles remained.

The core of the market of PPP projects is formed at the expense of projects over 1 billion rubles in volume. There are 158 such projects now with the volume of investment of 1.7 trillion rubles. Considering that the end user of the infrastructure is the population, the volume of investment, attracted in PPP projects per capita, can be the interesting comparative indicator. According to this criterium, Russia lags behind the majority of the countries so far. The comparison of the Russian expenses on the PPP projects per capita with such leading countries as Great Britain, is not in our favour, but our country is at the acceptable level in its group (Mexico, China, India).

The research, carried out by the authors, elicited some more facts, characterizing the market of PPP projects.

Concession still remains the main form of the implementation of the PPP projects: 2496 infrastructure projects $(82.5 \%)$ went through the stage of commercial closing. The volume of private investments in the concession projects exceeds 619 billion rubles (Table 1).

Table 1. Concluded concession agreements according to the spheres and administrative level of the authorities

\begin{tabular}{|c|c|c|c|c|c|c|}
\hline \multirow[t]{2}{*}{ Spheres } & \multicolumn{2}{|c|}{ Municipal } & \multicolumn{2}{|c|}{ Regional } & \multicolumn{2}{|r|}{ Federal } \\
\hline & 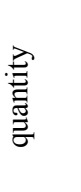 & 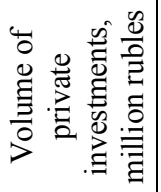 & 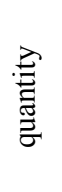 & 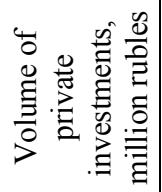 & 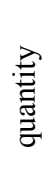 & 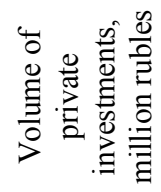 \\
\hline Social & 94 & 4511 & 49 & 25198 & 2 & 3077 \\
\hline Transport & 15 & 5813 & 15 & 147405 & 6 & 1314541 \\
\hline IT infrastructure & 2 & 615 & 8 & 10450 & 1 & 28900 \\
\hline Communal-and-energy & 2256 & 237708 & 34 & 18891 & & \\
\hline $\begin{array}{l}\text { Improvement and accompanying } \\
\text { technical infrastructure }\end{array}$ & 13 & 2501 & & & & \\
\hline Rural and hunting infrastructure & 1 & 5 & & & & \\
\hline Total & 2381 & 250601 & 106 & 201945 & & 166518 \\
\hline
\end{tabular}

Some projects (only 410) which have signs, similar to the PPP projects are also being implemented, but at the same time they are structured within other legal forms. Private investment obligations make up 871.4 billion rubles in such quasi-PPP projects. Examples of such projects are the following:

- the long-term investment agreement and the contract of life cycle, signed within the Federal Law "On Purchases of Goods, Works, Services as Separate Types of Legal Entities" No 223-FZ, July 18, 2011;

- the contract of life cycle within the Federal Law "On the Contract System in the Sphere of Purchases of Goods, Works, Services for Ensuring the State and Municipal Needs" No 44-FZ, April 5, 2013

- the corporate form within which the use of the basic principles of long-term partnership are fixed in the shareholders' agreements or other contracts;

- the long-term lease agreement of public property which means certain investment obligations of the tenant (standards of the Civil Code of the Russian Federation and the Federal Law "On Protection of the Competition", No 135-FZ, July 26, 2006

- 12 years is the average term of the PPP projects; 13 years is the average term for other forms; 
- the Volga federal district is the district with the greatest quantity of the PPP projects; The Central Federal district is the leader in terms of volume of investments;

- 1:4 is the ratio of the PPP projects, initiated by the private party (559 projects) to the projects started by public authorities ( 2137 projects).

So, the market of projects implemented on various principles of PPP develops in all the spheres and at all the levels.

But FAS decisions reduce the stability of the institute of PPP, undermine the investment basis of business.

The policy of FAS will affect the market of concession bonds not in the best way. Nowadays, 21 issues of the concession bonds for the total amount of 80 billion rubles are in the circulation. The most part of these bonds was redeemed by the large pension funds. It is important for the private pension funds to take into account the profitability to the rate of inflation, and as a rule, it was implemented via the mechanism of the fixed payments from the budget in the form of a payment of the concessor, which considered this the profitability, minimum for pension money. Besides, the agreements also provided some guarantees of the minimum profitability (contingent liabilities of the budget to pay if the income of the concessionaire is lower, than it has been established by the parties in the agreement), but because of the expanded interpretation of the position of FAS these provisions can be inapplicable.

These main problems were designated by FAS early in 2017 and still exist in 2019.

The mechanism of PPP and concession cannot work effectively in the conditions of such hopelessly outdated legislation.

Unfortunately, the analysis of the situation which is carried out within this research, proved that social and transport PPP projects are implemented generally according to the model of purchases, where the customer represented by the state, puts both the minimum characteristics and requirements, and all the details of the project, being guided by strictly administrative model of decision making, and the partner acts as the contractor; that contradicts the sense of such cooperation [9, 10]. The advantage of PPP and concessions are not only in the attraction of private means, first of all they are qualitative, modern decisions and the speed of the project implementation. The commercial success of the partner directly depends on the demand of the project at the consumer. In it the basic difference between concession and the state order.

The zones of responsibility of the private sector and the state have to be differentiated, so that each of the parties could perform its activity most effectively: the state has to formulate the task in terms of the solution of social problems, business has to find the best solution in terms of technologies and cost. The mechanisms of concession and PPP are thee alternative model of realization of infrastructure tasks, which cannot work effectively in the conditions of hopelessly outdated legislation. Today there is no elementary electronic form of selection of the partner. Until the concessions and public-and-private partnership are supplied with the administrative infrastructure, all the projects will be single-piece, and the model of such cooperation will not find broad application [11-12].

Some measures are also required for the solution of the existing problems:

1) differentiation of the legislation on PPP with the purchasing legislation, completions regarding establishment of the transparent procedure of the selection of the partner, inclusion of regulations on the deferred payments (so-called infrastructure mortgage) providing payment of construction of the facility after certain time and after delivery of this object into maintenance. Establishment of the postponed payments from the federal budget within "the infrastructure mortgage" will allow eliminating the mixture of concession and procurement procedures.

2) fixing of the principle of ensuring the competition in the Law on PPP as the logical and far-sighted decision which creates the opportunity for law enforcement officials objectively 
and to approach comprehensively the consideration of the disputes connected with the restriction of the competition during the implementation of the PPP project [13].

3 ) determining of the private partner by tendering in the form of the competition as one of the mechanisms of realization of the principle of ensuring the competition.

4) holding a competition which assumes the use of the complex system of definition of the winner, based on several criteria, including estimated, respectively, holding a competition, first of all has to be regulated by the principle of ensuring the competition [14]. And now (as the results of the research proved) $58 \%$ of these criteria do not work, $22 \%$ of the criteria are wrong in fact, $20 \%$ of these criteria are made up by the expert assessment, which becomes the most significant criterion (it is shown on the example of housing-andcommunal utilities in Table 2).

Table 2. Criteria of competitive selection for the right to contract the PPP in the housing sector [15]

\begin{tabular}{|c|c|c|c|c|}
\hline Criterion & $\begin{array}{c}\text { Initial } \\
\text { value }\end{array}$ & $\begin{array}{c}\text { Requirements } \\
\text { to change }\end{array}$ & $\begin{array}{c}\text { Criterion } \\
\text { weight }\end{array}$ & Comment \\
\hline Annual rent & 2.2 & increase & 0.06 & Wrong criterion \\
\hline $\begin{array}{c}\text { Terms of reconstruction of the water } \\
\text { supply system on the basis of hydraulic } \\
\text { model }\end{array}$ & 2 years & reduction & 0.1 & Does not work \\
\hline $\begin{array}{c}\text { Terms of reconstruction of the water } \\
\text { disposal system on the basis of } \\
\text { hydraulic model }\end{array}$ & 3 years & reduction & 0.1 & Does not work \\
\hline $\begin{array}{c}\text { Losses of water in networks, 5 years } \\
\text { since water supply establishment }\end{array}$ & 20 & reduction & 0.08 & Wrong criterion \\
\hline $\begin{array}{c}\text { Provision with water metering devices } \\
\text { on inputs in the apartment houses, \% }\end{array}$ & 95 & increase & & Wrong criterion \\
\hline $\begin{array}{c}\text { Qualitative characteristic of decisions } \\
\text { on reconstruction of subjects of the } \\
\text { contract }\end{array}$ & - & $\begin{array}{c}\text { assessment in } \\
\text { points }\end{array}$ & 0.2 & $\begin{array}{c}\text { Expert } \\
\text { assessment }\end{array}$ \\
\hline
\end{tabular}

\section{Conclusions}

The projects implemented on the principles of PPP have some distinctive signs: as a rule, they are socially directed, capital-intensive, they have the long term of realization and at the same time they have low profitability. But at the same time, the private funds raised by the means of the PPP mechanism allow significantly facilitating the load of the budget. This is very important in the present economic situation. The legal framework for the effective work of PPP is worked out both at the federal, and at the regional level. Considerable experience of legal regulation and implementation of PPP projects in various spheres of public life is already accumulated in the regions of the Russian Federation.

Forms of PPP, developing, represent the decision both already existing in the world practice and new decisions. During the evolution, the separate provisions regulating activity of private investors are corrected. The problems of legal regulation exist. But nevertheless, the analysis of the situation proves that the obstacles in the way of the effective mechanism of the interaction of business and the state are artificial and anyway they are surmountable.

The following measures are required for the solution of the existing problems:

1) differentiation of zones of responsibility of the private sector and the state;

2) differentiation of the legislation on PPP, with the purchasing legislation, improvement of the legislation in this area.

3) fixing of the principle of ensuring the competition in the Law on PPP;

4) determining of the private partner by tendering in the form of competition. 
Private investments into the development of national infrastructure (including transport) are growing even in the difficult modern conditions. Even judicial processes initiated by FAS have a positive consequence in this case, since they become a precedent for the further regulation of PPP in Russia.

The serious difficulty is that there are generally erudite economists in Russia, but not representatives of the legal science were engaged in the development of the issues of the formation and development of PPP. And the improvement of the PPP mechanism has to take place on the joint of economics and legal science.

\section{References}

1. F. Ban, K. Jain, C.H. Papadimitriou, Information Processing Letters, 145 (2019) DOI: $10.1016 /$ j.ipl.2018.12.009

2. E. R. Yescombe, E. Farquharson, Public-Private Partnerships for Infrastructure, (2018) DOI: 10.1016/B978-0-08-100766-2.00002-4

3. Organisation for economic cooperation and development, Principles for Private Sector Participation in Infrastructure (Paris, OECD, 2007)

4. Guidelines for Infrastructure Development through Build-Operate-Transfer (BOT) Projects, UNIDO (Vienna, UN, 1996)

5. Commission of the European Communities, Green Paper on Public-Private Partnerships and Community Law on Public Contracts and Concessions (Brussels, 2004)

6. UNCITRAL, Model Legislative Provisions on Privately Financed Infrastructure Projects (New York, UN, 2004)

7. UNCITRAL, Legislative Guide on Privately Financed Infrastructure Projects (UN, New York, 2001)

8. M. Marinelli, Built Environment Project and Asset Management (2019) DOI: 10.1108/BEPAM-01-2018-0021

9. A. G. Polyakova, E. M. Akhmetshin, et al., European Research Studies Journal, 21, 624-634 (2018)

10. K. Kim, H. Cho, D. Yook, Sustainability, 11(6), 1573 (2019) DOI: $10.3390 /$ su11061573

11. E. Vasilyeva, MATEC Web of Conferences, 170, 05005 (2018) DOI: https://doi.org/10.1051/matecconf/201817005005

12. S. M. Dhawade, S. S. Monga, Paripex - Indian journal of research, 7-11, 512513 (2018)

13. V. V. Zozulya, L. I. Goncharenko, A. V. Zuikov, G. N. Semenova, Journal of Advanced Research in Law and Economics, 8(5), 1629-1633 (2017)

14. Ashuri, H. Kashani, K. Molenaar, et al., J. Constr. Eng. Manag., 138, 545-557 (2012)

15. G. J. Power, M. Burris, S. Vadali, D. Vedenov, Transp. Res., Part A, 90, 50-68 (2016) 